shishiga - stock.adobe.com

\title{
UNDERSTANDING THE MECHANISMS BEHIND IYME DISEASE
}

DR CATHERINE BRISSETTE, BASED AT THE DEPARTMENT OF BIOMEDICAL SCIENCES AT THE UNIVERSITY OF NORTH DAKOTA IN THE US, IS ENGAGED IN A PROJECT THAT SEEKS TO UNDERSTAND MORE ABOUT LYME DISEASE. THE FINDINGS COULD LEAD TO THE DEVELOPMENT OF NOVEL THERAPIES TO TREAT AND PREVENT INFECTION

\section{TALK LIKE A BIOMEDICAL SCIENTIST}

PATHOGEN - any organism that can cause disease

\section{BORRELIA BURGDORFERI - the}

bacterium pathogen which causes

Lyme disease

HOST - the organism in which the pathogen resides, such as deer or humans in the case of Lyme disease
VECTOR - any agent which carries and transmits an infectious pathogen into another living organism, such as a tick in the case of Lyme disease

TROPISM - a biological phenomenon, indicating growth or movement of an organism in response to an environmental stimulus
Lyme disease is a bacterial infection that can affect humans if they are bitten by infected ticks. Symptoms of Lyme disease include a circular red rash, high temperature, headaches, muscle pain and fatigue. The infection is treated with antibiotics and most patients get better relatively quickly, but there are others who experience severe symptoms that can last for months.

There are approximately 500,000 cases of Lyme disease every year in the US and it is also prevalent across Europe and parts of Asia. Scientists are aware of how the disease is spread and how to treat it - especially when the infection is discovered early. However, there is still much we do not know about the bacterium that causes the disease (known as Borrelia burgdorferi), and why some people experience far more serious cases of the disease than others. It is also not known why some patients continue to suffer from longterm symptoms, even after treatment.

To develop understanding in these areas, $\mathrm{Dr}$ Catherine Brissette is conducting research that is centred on discovering how the microbes that cause the disease persist and cause long- term infections. Catherine is a biomedical scientist based within the School of Medicine and Health Sciences at the University of North Dakota in the United States. Some of the questions her team is seeking to answer include why Borrelia have a tropism for certain tissues, how Borrelia cause disease, and how Borrelia survive in the vector and the host.

HOW DOES CATHERINE PERFORM HER RESEARCH ON A DAY-TO DAY BASIS?

Some of the processes that Catherine and her team are engaged in are laborious - but that is often the case with research! "A typical experiment starts with growing the bacterium, which can take a week! A typical infection experiment starts with an intense day of inoculating mice, followed by waiting," explains Catherine. "Most of our experimental work, whether it is creating strains of Borrelia that lack a particular virulence factor, or an infection experiment to examine how the bacterium colonises the host, or what the host immune response looks like at a particular time point, is a lot of hurry up and wait." For this reason, the team tends to have several different projects ongoing at any one time, so that they can stagger the work and achieve results. 


\section{WHAT HAPPENS IN THE HUMAN BODY} WHEN A PERSON IS INFECTED?

Lyme disease is a tick-borne disease caused by tick bites. The tick will bite an animal infected by Lyme disease, such as small rodents and birds, and act as a vector through which the infection is transmitted to humans. The bacterium enters a patient through the skin after a bite and the immune response follows the bacterium. Borrelia itself does not make toxins, so the severity of the disease is dependent on how an individual's body responds to the infection.

There are a range of different symptoms, many of which are similar to flu. However, it can also cause temporary facial paralysis and even serious heart conditions that can lead to death. Borrelia target the skin, joints, heart and nervous systems but nobody is sure why this is - it is thought that certain surface proteins of Borrelia interact with certain host proteins which could influence where the bacteria end up in the body.

\section{WHAT METHODS DO CATHERINE AND} THE TEAM USE?

Animal models are critical to the research that Catherine is conducting. "We use both mice and ticks, because Borrelia is spread by ticks in nature. Using these models, we have shown how certain outer surface proteins in Borrelia contribute to the spread of the bacteria to different tissues and organs," says Catherine. "We have also shown that - contrary to what people used to think mice do get central nervous system involvement after Borrelia infection. This is important because, previously, people used monkeys to study the neurological effects of Lyme disease, but mice are better for research: there are many more tools and reagents available to do these studies, the research is cheaper, and does not require special facilities or training."

The studies revolve around three distinct (though related) focus groups: host-pathogen interactions, neuroscience and epigenetics, and the team combine all of them to aid their research. "We look at how Borrelia impacts the host response in the central nervous system, so there are the host-pathogen interactions and neuroscience interaction. Epigenetics (above the DNA) refers to changes in gene expression that are inherited (from cell to cell or even from parent to offspring) but are not due to changes in DNA sequence. So, there is a change in how genes are read," says Catherine. "Epigenetics may play a role in why symptoms can vary so widely between people, or why some people have persistent symptoms. For example, a host immune gene might be 'primed' to overreact to a Borrelia infection or might not be turned 'off' when the infection is cleared, because of an epigenetic mark."

\section{WHAT HAS THE TEAM DISCOVERED} ABOUT LYME DISEASE SO FAR?

Some of the team's results are focused on how the disease affects the nervous system; they have discovered that Borrelia colonise the lining of the brain which results in a particular immune response within the brain itself. What is particularly fascinating about this is that the bacteria are not actually in the brain when this reaction occurs. The key factor in the severity of Lyme disease is how the host responds to the bacterium - which differs from person to person. It is likely that the variance in symptoms depends on several factors, such as genetic differences, environmental factors, what particular variety of Borrelia is inside the patient and where the bacterium invades the nervous system.

\section{One of the chief successes that Catherine and} the team have had so far is convincing the wider field of biomedical sciences that using mice was a viable model system to study the neurological effects of Lyme disease. Indeed, Catherine considers that achievement to be especially validating for her professionally. It will pave the way for further studies in the area which could well lead to additional developments in our understanding.

\section{HOW CLOSE ARE WE TO THE}

DEVELOPMENT OF NOVEL THERAPIES AGAINST BORRELIA BURGDORFERI?

Catherine believes we are very close to an

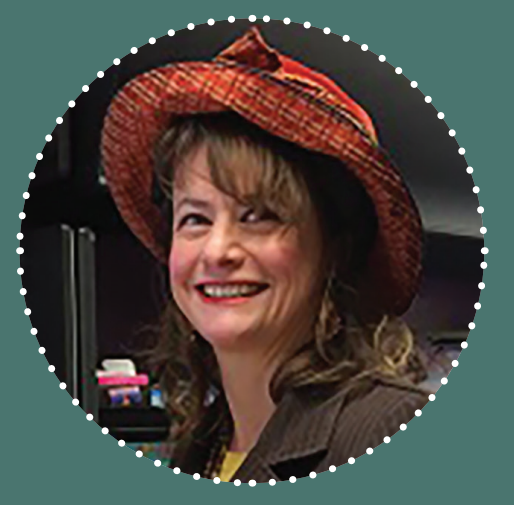

DR CATHERINE BRISSETTE

Associate Professor, Department of Biomedical Sciences, School of Medicine and Health Sciences, University of North Dakota, USA

$\bullet \bullet \bullet \bullet \bullet \bullet$

\section{FIELD OF RESEARCH}

Biomedical Sciences

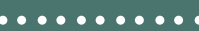

\section{RESEARCH PROJECT}

Catherine's work is focused on the hostpathogen-vector interface involved in Lyme disease. Ultimately, her laboratory

wants to discover how the microbes

responsible for the disease persist and cause long-term infections in patients.

$\ldots \ldots \ldots \ldots$

FUNDERS

National Institutes of Health, University of North Dakota, US Department of Defense

effective novel therapy (or combination of therapies) being developed. Of course, treatments already exist for Lyme disease, but they are not effective for all patients. There is a lot of work being done on different antibiotic regimens, treatments that can be administered before an individual is exposed to high-risk populations, and work is afoot to create a Lyme disease vaccine.

The key to the majority of cases is early detection, as treatments are much more effective the earlier they are administered. However, there will always be people who experience more serious reactions, so novel therapies to combat long-term symptoms are the holy grail in this research field. Fortunately, Catherine and her team continue to conduct research which will accelerate understanding and could one day lead to treatments and novel therapies that see adverse reactions to Lyme disease confined to the past. 


\section{ABOUT BIOMEDICAL SCIENCES}

The biomedical sciences get their name from the fact that proponents of it attempt to explain health in terms of biology. Biomedical scientists often conduct research that is designed to understand more about anatomy and systems, including mechanisms like the heart and brain.

It is difficult to overstate the importance of biomedical science as a distinct field, especially when we consider that it has led to increased knowledge about what causes infectious diseases. We have all seen the impact of COVID-19 and the efforts being made to curb the spread of the virus.

However, it is not just infectious diseases that biomedical scientists are concerned with - Catherine's research is centred on understanding more about the mechanisms that lie behind Lyme disease. The ultimate hope is that by increasing understanding about why some patients experience more severe symptoms than others, suitable treatments, cures and preventive measures can be developed. Biomedical science is just as important today as it was 100 years ago, although as understanding and technology develops, so too do the methods and approaches that can be undertaken.

WHAT DOES CATHERINE FIND REWARDING ABOUT BIOMEDICAL SCIENCES?

Catherine has enjoyed solving puzzles since she was a child and her role as a biomedical scientist enables her to pursue this interest on a near-daily basis. Of course, the puzzles she is attempting to solve are more difficult than, say, a 1000-piece jigsaw, but the overall objective (solving a challenge) is similar! Catherine also enjoys learning new things and she tells us that even though she did not want to be a physician, she wanted to be close to medicine and do work that might benefit patients. Her current work certainly involves that!

WHAT ISSUES WILL FACE THE NEXT GENERATION OF BIOMEDICAL

\section{SCIENTISTS?}

In many ways, the issues biomedical scientists may face in the future will likely not differ too much from those facing scientists of other fields. "Higher education is changing, and academic jobs may be hard to find. Luckily, what used to be considered 'alternative fields' are not alternative anymore, so there are opportunities in science writing, industry, law and advocacy," explains Catherine. "Diversity and equality issues are still a big problem, but institutions and society seem to be paying more attention, and I am hopeful this next generation will make great strides."

\section{EXPLORE A CAREER IN BIOMEDICAL SCIENCE}

The Annual Biomedical Research Conference for Minority Students (ABRCMS) is a great conference for students that happens in the US every November. ABRCMS promotes STEM for underrepresented students, but their conferences and resources are available to everyone.

- Catherine recommends reaching out to researchers in the

field via email or social media. When at college, look for research opportunities in labs and volunteer if you can. Tell your instructors you are interested in research and they will often help you find a place.

- From working in a lab as a research technician, to a faculty or industry position with a $\mathrm{PhD}$, the salary for a biomedical scientist can vary hugely!

\section{PATHWAY FROM SCHOOL TO BIOMEDICAL SCIENCE}

Catherine suggests that students study the basics - biology, chemistry, biochemistry and physics, but also think about what interests you. "So much science is collaborative these days and having a broad base of all the sciences can only be beneficial," says Catherine. "Save some credits for learning something you enjoy - I took psychology courses and Greek mythology just because they interested me!'

You could do a degree accredited by the Institute of Biomedical Science, or train through the NHS Practitioner Training Programme and complete a degree in healthcare science. Your course will include work placements so you can get industry experience and evidence to complete a training portfolio. You'll need this to register to work.

https://nationalcareers.service.gov.uk/job-profiles/biomedical-scientist

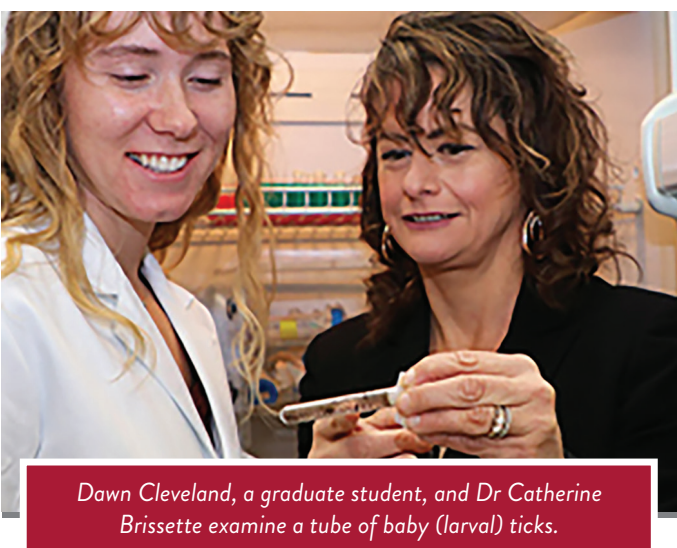

\section{CATHERINEES TOP TIPS}

01 Perseverance is the key to success. If you stick at what you are doing (even when it is difficult), you will eventually get the results you want.

02 Try and take care of your mental health. The job of a scientist can be stressful, so it is important to find ways of managing your stress from the outset.

03 Read broadly! This will help keep your mind alive to possibility and retain curiosity. I believe keeping an open mind is extremely important because you never know what is around the corner - often discoveries will come from unexpected places. 


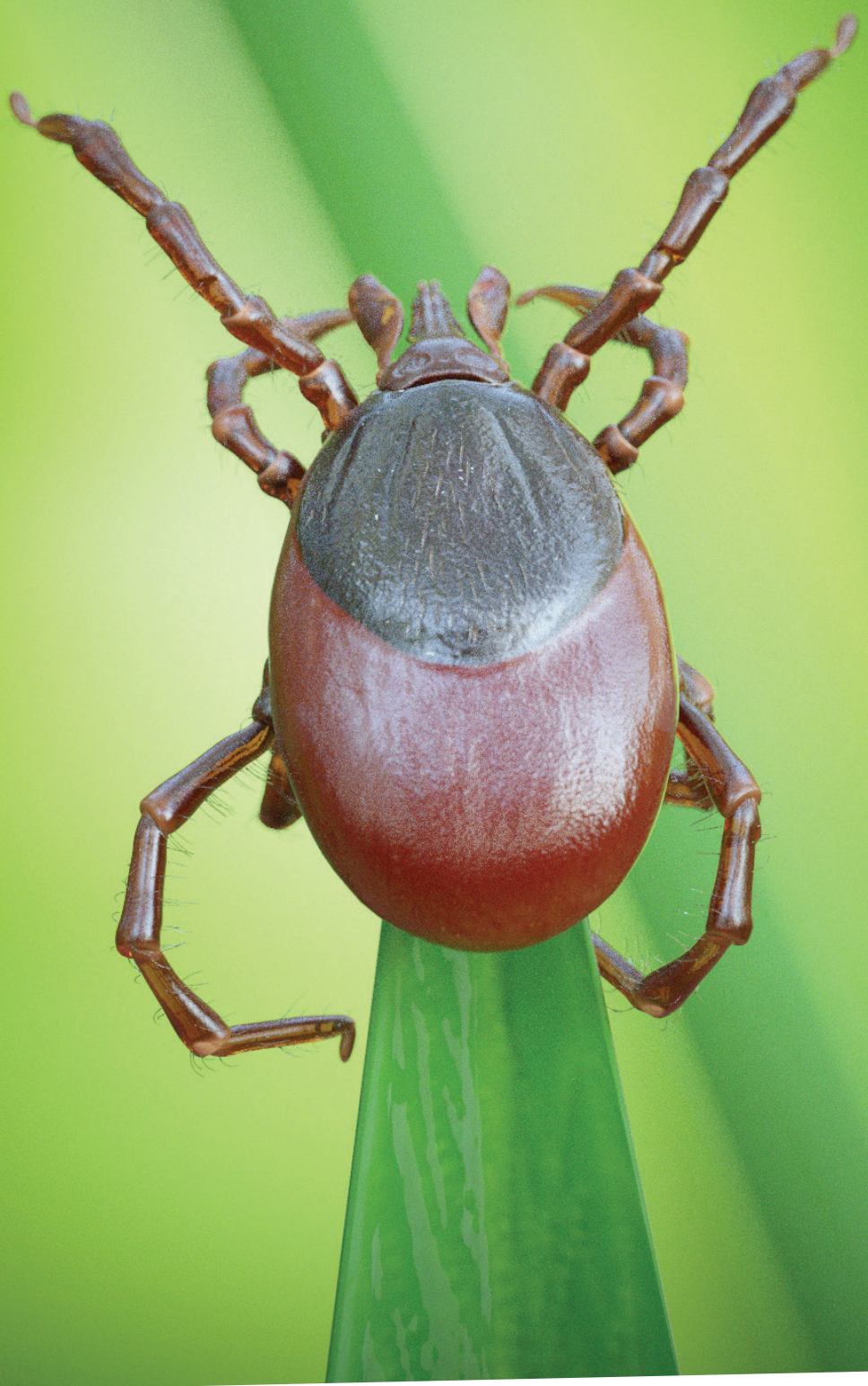

\section{HOW DID CATHERINE BECOME A BIOMEDICAL SCIENTIST?}

WHAT WERE YOUR INTERESTS AS A CHILD?

I was interested in many things, including nature, animals, music, art and books.

WHO OR WHAT INSPIRED YOU TO BECOME A SCIENTIST?

My parents! My dad was a research scientist with the US Forest Service and my mom was a medical technologist. From when I was six weeks old until I graduated from high school, one or both of my parents was in school! I also love puzzles and consider my role as a scientist to be all about solving puzzles.

WHAT ATTRIBUTES HAVE MADE YOU SUCCESSFUL AS A SCIENTIST?

Persistence. Then there is reading a lot and learning about other scientific fields. Sometimes you get great ideas from a talk or presentation that has nothing to do with your own research. Having great mentors is also very important and collaborating with other scientists too.

\section{HOW DO YOU SWITCH OFF FROM} YOUR WORK?

I enjoy listening to music and have created a playlist of tunes designed to invigorate me! I also enjoy playing music - I play clarinet in a city band and I am currently learning bass guitar. I also like running and doing physical work outside, such as gardening.
AMBITIONS FOR THE FUTURE?

Getting grants and publishing papers always feels good but seeing my students and trainees do well is the best achievement. I would love to see one of my trainees follow in my footsteps and get a tenure track position. For myself I would really like to make full professor! 